\title{
Nietzsche: Estilística para uma nova linguagem do pensamento*
}

\author{
Carmen Gómez García**
}

Resumo: $O$ artigo procura realizar uma análise do estilo de Nietzsche. O filósofo faz uso da linguagem para fundamentar e lançar suas críticas a todos os campos do saber. Desse modo, ele leva a linguagem, a matéria-prima do artista, a uma crise. Com isso, ele tenta, por meio de uma escrita renovada, a criação de um mundo mais artístico. Ao estabelecer uma relação entre estilo e vida, Nietzsche faz que a corporeidade desempenhe um papel fundamental em seus escritos.

Palavras-chave: estilo, linguagem, corpo, vida.

* Tradução de André Luís Mota Itaparica.

** Universidade Complutense de Madri, Madri, Espanha.

ORCID: https://orcid.org/0000-0002-8717-5350

Correio eletrônico: carmengomezg@pdi.ucm.es 
García, C. G.

„Den Stil verbessern - das heisst den Gedanken verbessern“. ${ }^{1}$

As páginas seguintes são dedicadas ao estilo de um filólogo que introduziu a linguagem, ela mesma, no âmbito do pensamento (como disse Foucault em As palavras e as coisas). Ele fez uso da linguagem para fundamentar e lançar suas críticas a todos os campos do saber. Nietzsche tomou a liberdade de colocar a linguagem, a matéria-prima do artista, em crise. Foi quem teve de propor, por meio de uma escrita renovada, a criação de um mundo melhor, ou, pelo menos, artístico.

O fato de que, já em 1873, Nietzsche pretendia escrever um livro sobre a leitura e a escrita, dedicando um de seus capítulos ao estilo, e que sua obra (como o Zaratustra, por exemplo) esteja recheada tanto de indicações e recomendações estilísticas quanto de críticas à prosa de outros e louvores à própria, permite entrever a importância que o filólogo-filósofo concedeu ao estilo, estilo que transformou a língua alemã e sobre o qual, ao menos em espanhol, não há uma análise detalhada, apesar de que, como diz Rüdiger Safranski:

Para Nietzsche, um pensamento só pode ter uma força vívida e variável quando ele se incorpora numa linguagem de grande beleza e expressividade. $\mathrm{O}$ senso do estilo é, em Nietzsche, quase um sentido físico. Ele reage à linguagem com sintomas físicos, da vitalidade e prazer ao abatimento e malestar. Ele procura por frases que comovam a ele e aos outros, formulando-as e dando-lhes, no andamento, ritmo (Safranski, 2000, p.182).

Com efeito, antecipando o aspecto do estilo de que quero tratar, a corporeidade determina o estilo de Nietzsche.

Os seguidores de Nietzsche, já no fim do século XIX, falavam de uma "linguagem heroica e profética" (Gauger, 2007, p.126), de uma nova forma de escrever, a qual celebravam como desconhecida até então; outros criticavam o pensamento de um filósofo cuja validade

1 Melhorar o estilo - isso quer dizer melhorar o pensamento (WS/AS 131, KSA 2.610).

172 | Cad. Nietzsche, Guarulhos/Porto Seguro, v.41, n.1, p. 171-191, janeiro/abril, 2020. 
consideravam apenas retórica. A maioria, sem dúvida, rendia-se a sua fascinação, da qual diziam residir tanto em seus conteúdos amorais, desprovidos de dogmas, ideologias e carentes de escrúpulos, como num estilo de modo algum casual. Mais ainda: Gottfried Benn declarou que o expressionismo literário nada mais era senão uma exegese de Nietzsche; ${ }^{2}$ enquanto, em relação à forma, afirmou:

Nietzsche vem e a linguagem se inicia, uma linguagem que não quer (nem pode) nada além de fulgurar, demonizar, arrebatar, atordoar. Ela celebra a si mesma, rasga o humano em seu organismo estreito, mas também violento. Ela torna-se monológica, e mesmo monomaníaca. Um estilo trágico, um estilo de crise, híbrido e terminal (Benn, 1957, p. 203).

Esse julgamento, que Gottfried Benn emitiu numa carta dirigida a Dieter Wellershoff em 22 de novembro de 1950, guarda grande semelhança com aquilo que, quarenta anos antes, Thomas Mann tinha expressado. Ele sustentava que a influência civilizatória de Nietzsche consistia menos em sua doutrina e mais no modo como que ele a professou; sua influência, assegurava, residia num fortalecimento, alento e agudização imensos do exercício da escrita, da crítica e do radicalismo na Alemanha: "ele emprestou à prosa alemã sensibilidade, leveza artística, beleza, agudez, musicalidade, ênfase e paixão - inteiramente inauditas até então e de uma influência inescapável a todo aquele que, depois dele, pretendia escrever em alemão" (Mann, 1983, p. 86). Assim falava Zaratustra converteuse num livro de culto em parte pela constante superação dialética do indivíduo, mas também por sua dicção: "Deve-se considerar Nietzsche, em primeiro lugar e sobretudo, como o criador de um novo

2 "Pois, no que nos diz respeito, nosso pano de fundo foi Nietzsche: dilacerar sua essência íntima com palavras, o impulso de se expressar, de formular, de ofuscar, de brilhar diante de todo perigo, sem temor dos resultados, a supressão do conteúdo em nome da expressão - foi esta sua existência" (Gotffried Benn, na introdução à antologia expressionista Lyrik des expressionistischen Jahrzehnts. München: dtv, 1962, p. 10). 
García, C. G.

estilo, que dotou a língua alemã de um ritmo novo não cultivado até então" (Gonzáles, 2000, p. 44). ${ }^{3}$

A analise do estilo de Nietzsche obriga a uma breve pausa na origem latina do término, "stilus", já que se pode bem afirmar que tal estilo é o resultado da forma que se tem de manejar e usar a sua ferramenta: a língua, pois, assim como o vocabulário designa entidades, fatos e acontecimentos, e a sintaxe constrói relações lógicas entre eles, o estilo remete à capacidade artística do autor, para Nietzsche requisito máximo e critério de valoração que ultrapassa a correção normativa. Enquanto o ser humano assume uma língua que lhe é imposta, o estilo é uma consequência individual e singular que resulta de uma educação, de uma auto(de)formação ou de um talento e meio de distinção, algo que os escritores do Fin de siècle europeu apreciavam enquanto atitude aristocrática e gesto próprio de um dandy da palavra. O estilo, manifestação de um desvio que se evidencia como norma, supunha um ideal que implicava uma glorificação de algum modelo escolhido do passado, uma crítica ao presente e um esboço de futuro. Essa preocupação com o estilo, com a distinção do que é habitual, responde, como não podia deixar de ser, a um projeto comum, presente na literatura produzida em torno da virada do século, que determinou o conjunto dos escritores da época. Tal reflexão linguística, estilística e formal obedece a vários motivos: ${ }^{4}$

- A concepção da realidade e a nova forma de relacionamento do ser com o mundo se modificaram substancialmente; surge, sobretudo, um protesto contra a mecanização, o cientificismo e o empirismo inerentes ao final do século XIX.

- $\quad$ Consequentemente, se transformam a maneira de compreender o ser e a relação do sujeito com a linguagem, seu meio de

3 Na mesma página é feita referência a um comentário de Gustav Landauer, segundo o qual não se pode aprender muito de Nietzsche, embora sua linguagem seja admirável.

4. Cf. Helmut Koopmann, 1997, p. 12.

174 | Cad. Nietzsche, Guarulhos/Porto Seguro, v.41, n.1, p. 171-191, janeiro/abril, 2020. 
apreender o que lhe cerca. Isto deriva numa nova concepção da língua, que deve dar conta do metalinguístico com meios linguísticos: o uso da língua se torna conscientemente nãoconvencional a fim de capturar a vida. Uma escrita tradicional é, definitivamente, impensável.

Essa busca pelo ser, pela existência, pela vida e pela necessidade de tomá-lo pelas palavras supõe que a arte assuma uma importância muito maior do que a que lhe foi atribuída até agora. Leben, vida, vitalismo, é o verdadeiro tema e o máximo denominador comum de toda a produção literária na virada do século, da qual Nietzsche havia sido seu principal propagador. Nietzsche opôs o vitalismo à saturação da história, segundo ele perigosa e hostil ao indivíduo, pois debilita a personalidade e perturba o instinto. Segundo essa crítica, o indivíduo duvida de si mesmo, não se arrisca, mas se disfarça de homem culto, sábio, poeta, político (HL/Com. Ext. II 5, KSA 1.280). Nietzsche resume isso no Crepúsculo dos ídolos:

Nossa cultura padece de nada menos do que de um excesso de uma ociosidade petulante e de uma humanidade fragmentada; nossas universidades são, a contragosto, a verdadeira estufa para essa espécie de atrofia instintiva do espírito (GD/CI, O que falta aos alemães, 3, KSA 6.105).

Em vez de formar indivíduos soberanos, afirma Nietzsche, a cultura apresenta animais gregários, dóceis e medíocres que povoam estados e igrejas. Quando um estado favorece a cultura, diz Nietzsche em Schopenhauer como educador, "apenas a favorece para favorecer a si mesmo, e jamais concebe que haja um fim que seja superior a seu bem e a sua existência" (SE/Co. Ext. III, KSA 1.400). Os intelectuais levaram a sério a exortação nietzschiana a uma nova forma de ensinar, que passa por aprender a ver, a pensar, a falar e escrever através do cuidado com os instintos. Assim, Rainer Maria Rilke escreveu: “Aprendo a ver. Não sei por que tudo penetra mais profundamente em 
García, C. G.

mim e não se detém no lugar onde, contudo, é sempre o fim. Possuo um interior que não conhecia" (Rilke, 1910, p. 10).

A esse respeito, cabe sublinhar que vida e linguagem já não constituíam uma unidade, como postulava, ao contrário, uma concepção monista muito produtiva representada por Gustav Theodor Fechner. Percebia-se que a língua - diriam Nietzsche e Georg Simmel - se encontrava adoentada por causa das convenções externas, haviase tornado produto da língua da cultura, isto é, produto da educação, da formação e de suas manifestações culturais, se achava submetida a um discurso estabelecido. Por isso, a crítica da linguagem, em realidade, não era senão uma crítica à cultura em seu conjunto, à sociedade que perverte e violenta a realidade também por meio da língua - na época era comum a comparação da língua com a imagem de uma moeda desgastada: só tem valor de troca, embora tal valor se reduza com o tempo. Por isso Nietzsche, assim como seu predecessor de sua concepção artística da linguagem, da língua como artefato, Gustav Gerber, sustentava que a "língua é arte", no sentido de que a língua trata de reproduzir estímulos, imagens de sensações, de modo que o ser humano se afasta da vida natural para adentrar um mundo artificial, um sistema de sons e imagens, isto é, um meio que transmite "coisas" (WL/VM, KSA 1.873-890).

Não obstante, pouco se tem analisado ou refletido como Nietzsche escrevia, em que se funda o estilo que ele afirmou ter constituído sua maior contribuição às humanidades, estilo que, inclusive, ele mesmo afirmou ter servido para revolucionar a língua alemã e ter ampliado os limites do idioma, levando-o a territórios até então inexplorados.

Nietzsche atribuía a sua filosofia um significado tão relevante quanto o estilo de que se servia para difundi-lo. Numa carta de 1884, escreve a seu amigo Erwin Rohde:

Imagino, com esse Zaratustra, ter levado a língua alemã à perfeição. Depois de Lutero e Goethe, havia ainda um terceiro passo a ser dado - veja, velho 
amigo do peito, se força, flexibilidade e tom agradável já estiverem, em nossa língua, tão lado a lado. Leia Goethe depois de uma página de meu livro - e você sentirá que aquele "ondulatório", que Goethe tinha como característico, não permanece estranho ao artista da linguagem. Mantive uma linha varonil diante dele, sem contudo, com Lutero, ter caído na malcriação. Meu estilo é uma dança; um jogo de simetrias de toda sorte e um saltar e zombar dessas simetrias. Isso vai até a escolha das vogais.

No Ecce homo, ele continua no quarto capítulo. "Por que escrevo livros tão bons":

Antes de mim não se sabia o que se pode fazer com a língua alemã, - o que se pode fazer com língua em geral. - A arte do grande ritmo, do grande estilo do período para a expressão de um gigantesco subir e descer de uma paixão sublime, sobrenatural, foi só comigo descoberta (EH/EH, Por que escrevo livros tão bons 4, KSA 6.304-5).

Com essas citações se tornam manifestos, como diria Alexander Nehamas, o caráter, a escrita e o pensamento "essencialmente hiperbólicos" (Nehamas, 1985, p. 51) de Nietzsche; em segundo lugar, se evidencia a concepção da língua como artefato - no que concerne à "maleabilidade" da linguagem, à tarefa de esculpir a língua -, e, em terceiro e último lugar, se assiste a uma fusão de vitalidade e corporeidade presentes, no que diz respeito à gestualidade e às paixões, à oralidade/musicalidade e à dança, que necessariamente culmina no jogo, no riso. Não é à toa que o decálogo do estilo que Nietzsche escreveu em 1882 poderia condensar-se em dois pontoschave: 1) a inserção de elementos poéticos em toda escrita e 2) o preceito da oralidade/corporeidade textual patente no desenho gráfico de suas páginas.

$$
\text { * } * * *
$$

Em agosto de 1882, Nietzsche escreveu um texto para Lou Andreas-Salomé durante os dias felizes passados em Tautenburg: 
García, C. G.

"Sobre a doutrina do estilo", uma espécie de decálogo bem ao estilo de seu autor (tinha escrito, também, em 1876, seus dez mandamentos do livre-pensador (Die zehn Gebote des Freigeistes):

1. O mais necessário é a vida: o estilo deve viver.

2. $\mathrm{O}$ estilo deve ser adequado a você, no que diz respeito a uma pessoa determinada com quem você queira se comunicar (lei da dupla relação).

3. Deve-se primeiro saber exatamente: "falaria e exporia isto de tal e tal maneira" - antes que se permita escrever. A escrita deve ser uma imitação.

4. Pelo fato de faltar ao escritor muitos dos meios do orador, ele deve, em geral, ter como modelo uma forma de exposição bastante expressiva: o reflexo disso, o que foi escrito, sairá necessariamente mais pálido.

5. A riqueza na vida se revela na riqueza dos gestos. Deve-se aprender tudo, o tamanho e a extensão das frases, a pontuação, a escolha das palavras, as pausas, a sequência dos argumentos - como gestos.

6. Cautela com o período! Têm direito ao período os homens que possuem grande fôlego também na fala. Para a maioria, o período é uma afetação.

7. O estilo deve provar que se acredita em seus pensamentos, e que não apenas os pensa, mas os sente.

8. Quanto mais abstrata for a verdade que se queira ensinar, mais se deve, primeiro, conduzir os sentidos em direção a ela.

9. A cadência do bom prosador consiste na escolha de seus meios para se aproximar da poesia, mas sem jamais ultrapassar a fronteira. 
10. Não é inteligente nem de bom tom antecipar as objeções mais fáceis ao leitor. É bem inteligente e de muito bom tom deixar que o próprio leitor expresse a última quintessência de nossa sabedoria (NF/FP de julho-agosto de 1882, 1[109], KSA 10.38-39).

Antes de tudo, é evidente que este decálogo, como afirma Helga Bleckwenn (1992), está ligado, embora de forma crítica, a uma tradição da estilística perpetuada no sistema escolar alemão e, por conseguinte, indica uma intenção didática que contraria os postulados normativos. Por outro lado, ele gira em torno de dois temas tão nietzschianos quanto da época: o primeiro é o termo "Leben", na verdade conceito consubstancial à obra nietzschiana, mas também metáfora fisiológica que remete ao corpo, à natureza (pontos 1 e 5 do decálogo); o segundo, a oralidade, ela mesma inerente à corporeidade dos "Gebärde" (gestos, expressões faciais), já presente na concepção do decálogo, que parte de una situação comunicativa em que se aprecia o principio da adequação (Angemessenheit como virtude central da retórica) e da "dupla relação", que implica que todo estilo se conforma em virtude do destinatário (ponto 2). Apesar do preceito de individuação ("O estilo deve ser adequado $a$ você"), o estilo requer o encontro de duas individualidades. Por outro lado, escrever não pode se apartar, se tornar independente da voz viva, da palavra proferida, do corpo (ponto 3). Trata, portanto, de uma situação fictícia de oralidade, de alguém que se dirige a um destinatário concreto, e de sua transformação em linguagem escrita mediante um "estilo vivo", de compreender as palavras em seu valor performativo, de assumi-las como gestos e, em consequência, empregá-las, senti-las como algo dotado de vida (Nietzsche fala inclusive do "odor das palavras" em $O$ andarilho e sua sombra (WS/AS 119, KSA 2.604; Cf. ponto 7).

Tal "estilo vivo" ou, em outros termos, a oralidade/corporeidade do texto se revela nas marcas gráficas dos escritos nietzschianos, no uso particular e extremo de uma pontuação e signos diacríticos que, ao 
García, C. G.

modo de uma partitura musical, assinalam como as frases devem ser proferidas, qual é o ritmo, o tom, a intensidade, o volume, como devem ser experimentados ("O estilo deve viver", reza o primeiro ponto do decálogo citado); isto é, a oralidade, a corporeidade e, com elas, a emotividade como principio retórico. Mediante a experimentação e corporificação dos textos em sequências rítmicas, recitadas, Nietzsche, defensor de um estilo sensorial-estético, inclusive teatral, libera a palavra do mundo ordinário da linguagem, como dizia no Crepúsculo dos ídolos. Recordemos que, retomando sua crítica à linguagem, esta, a linguagem, já "vulgariza" o que se fala. A palavra distorce e inclusive falsifica as vivências, pois apenas simplifica, informa, dissolve o singular em algo comum: "Em relação à música, toda comunicação por meio de palavras é de envergonhar; a palavra abrevia e emburrece; a palavra despersonaliza; a palavra faz do invulgar vulgar", assegura em 1887 (NF/FP do outono de 1887, 10[60], KSA 12.493).

Então que forma empregar a palavra? Como escrever? Como transmitir o pensamento?

No Ecce homo, Nietzsche descreve, de novo, com precisão, a "lei da dupla relação" (ponto 2), como o equilíbrio entre a orientação comunicativa e uma intenção expressiva individual:

Comunicar um estado, uma tensão interna, um páthos através de signos, incluindo o tempo desses signos - este é o sentido de todo estilo; e, considerando que em mim a multiplicidade de estados internos é extraordinária, há em mim muitas possibilidades de estilo - a mais multifária arte do estilo que um homem já possuiu. Bom é todo estilo que realmente comunica um estado interno, que não se equivoca com os signos, com o tempo dos signos, com os gestos - todas as leis do período são arte dos gestos. (...) Supondo sempre que haja ouvidos - que haja aqueles que sejam capazes de um páthos semelhante e que mereçam que não faltem aqueles com quem possam se comunicar" (EH/EH, por que escrevo livros tão bons 4, KSA 6.304). (Pontos 4 e 5; gestos) 
Também neste trecho os elementos paralinguísticos são interpretados semioticamente como Gebärde, e se colocam em combinação com o período (ponto 6). Acrescente-se o motivo do ouvido, que é empregado de forma metonímica para aludir à capacidade de decodificação do receptor. A seção 246 de Para além de bem e mal trata desta capacidade ou incapacidade do receptor, "o terceiro ouvido":

Que martírio são os livros escritos em alemão para aqueles que possuem o terceiro ouvido! (...) Como [o alemão que lê livros] lê mal, preguiçosamente, a contragosto. (...) Que não se pode ficar em dúvida quanto às sílabas ritmicamente decisivas, que se deve sentir a quebra de toda simetria rigorosa como desejo e estímulo, que cada staccato, cada rubato enseja um ouvido fino e paciente, que adivinha o sentido na sucessão de vogais e ditongos, e como estes, em sua sequência, podem ser coloridos e recoloridos de forma delicada e rica: quem, entre os leitores de livro alemães está disposto o suficiente a reconhecer deveres e exigências cuidadosas e a escutar a tamanha arte e desígnio na linguagem? (JGB/BM 246, KSA 5.189)

Nietzsche defende a crença de que os modernos não têm direito a fazer períodos tão longos (ponto 6), para concluir com a afirmação de que apenas os pregadores sabiam, na Alemanha, "qual é o peso de uma sílaba" ou de uma palavra; "até que ponto uma frase golpeia, salta, se precipita, corre, flui". Ele sustenta que, nos púlpitos, se sabia que a consciência tinha ouvidos (em alemão: "Gewissen in seinen Ohren"); para Nietzsche, filho de pregador protestante, a obra mestra da prosa escrita em alemão é a tradução de Lutero, obra de um pregador, única obra que se enraizou nos corações alemães, assegura. De novo, redunda na oralidade, na criação daquele estilo vivo que retorna a uma língua sensorial, mediante a elaboração de períodos adequados - entendendo por período, como afirma em Para além de bem e mal, um todo fisiológico, na medida em que está contido numa só respiração - e a restituição de elementos sensoriais, a assunção verbal de sensações, a fim de que o terceiro ouvido realize emoções que, de 
García, C. G.

forma supralinguística, se expressam em linguagem corporal (veja-se o ponto 8). Trata-se de um modo de discurso que seduz primeiro pelos sentidos o que argumenta mediante a razão, apoia-se em sensações antes que em argumentos, que vincula emocionalmente autor, leitor e tema.

Com esse propósito, Nietzsche recorre aos elementos suprassegmentais da linguagem, isto é, a variáveis fonéticas ou fonológicas que transmitem informação paralinguística. Para isso, ele forçou a grafia e a tipografia de seus escritos, obtendo um uso particular da língua, que procura reproduzir a oralidade perdida nos textos impressos. Tomando um exemplo, o prólogo de $O$ caso Wagner, publicado em 1888 (editorial C. G. Naumann, de Leipzig) ${ }^{5}$, se observa uma serie de características que bem poderiam denominar-se comuns à obra de Nietzsche e que recorrem à corporeidade da palavra escrita:

1. Antes de tudo, observa-se o uso de uma fonte incomum nos textos da época, a antiqua, que se opõe, não apenas esteticamente, ao gosto de seus contemporâneos, que publicavam em letra gótica. Desse modo, uma marca especial lhe confere o aspecto de um quadro, de obra de arte também visual.

2. Em segundo lugar, o uso da pontuação é chamativa, ao utilizar uma quantidade inusitada, além disso em lugares inesperados, como o travessão (depois de vírgula, ponto, dois pontos) ou três pontos, que só são utilizados na esfera privada e na prosa narrativa. Da mesma forma, Nietzsche usa e abusa das aspas e dos espaços, assim como de frases e parágrafos de extensão desigual, o que fornece à página uma imagem que suscita inquietude. Quanto às "lacunas", a ausência de palavras requer tanto espaço quanto as palavras em si mesmas. Dois aforismos de Para além de bem e mal (277 e 278) começam com um travessão “- Péssimo!"

5 Cf. Heinz Schlaffer: Das entfesselte Wort: Nietzsches Stil und seine Folgen. Múnich: Hanser, 2007, p. 24. Naumann, a editora mencionada, respeitou as instruções do filólogo, que insistia em fazer uma edição a mais estética possível, em completo acordo, por outro lado, com as convenções da época.

182 | Cad. Nietzsche, Guarulhos/Porto Seguro, v.41, n.1, p. 171-191, janeiro/abril, 2020. 
ou "- Andarilho, quem é você?" e terminam com um enxurrada de signos de pontuação: " - A melancolia do tudo acabado!..." e “"Mais uma máscara! Uma segunda máscara!'...".

Enfim, todos esses signos, enfim, ainda mais nos primeiros textos, são pensados para comunicação oral, para a diferenciação acústica e sensível do que está escrito, a fim de incitar a reflexão a um leitor que nunca é passivo e que lê lentamente, ou, pelo menos, que o texto seja reproduzido com mais ou menos paixão, com mais ou menos velocidade. São as marcas textuais de um filólogo que se refere, se não ao aprendiz de orador, ao compositor, que criava partituras nos textos, nos quais ele trabalhava como se fosse um pentagrama. Nietzsche alterou o tempo e o tom da leitura, ampliando o espaçamento entre caracteres e palavras, introduzindo pausas e variações de velocidade e de intensidade, ao modo do discurso interior, despertando no leitor a ideia de aumentar ou diminuir a intensidade da voz. Em outras palavras, Nietzsche fornece a seus textos a possibilidade de incorporar as palavras, atribuindo temporalidade aos caracteres escritos. Seus períodos, adaptados à respiração real, produzem um sentimento de veracidade que aumenta com a inserção de imprecações como "Wohlan!" ("Muito bem”), uma interjeição própria ao discurso oral, que, como tal, implica uma modificação de tom, intensidade, que desperta, no leitor, a ilusão de ser o verdadeiro destinatário que escuta o monólogo do autor. A palavra morta, escrita, ganha vida graças ao leitor, de quem depende seu significado, sua existência.

Do mesmo modo, como marcas da oralidade no texto, são usados bordões ("muito bem", o "quer dizer", "isto é de fato", "entendase"), repetições sobretudo em grupos de três em três, mudanças de ritmo, orações interrompidas e cortadas de propósito... indicadores, todos eles, de um páthos característico do autor. Por outro lado, com frequência, tal como ocorre nos aforismos, as frases concluem com signos que revelam um pensamento inconcluso, em virtude do qual 
García, C. G.

induzem à reflexão, à conjectura, ao enigma. “Quem pensa em palavras pensa como orador e não como pensador", diz Nietzsche em Para a genealogia da moral (GM/GM III 8, KSA 5.354). Nietzsche buscava o leitor lento, que refletisse para além do escrito, que completasse os espaços em branco reservados a uma verdade ainda não proferida (ponto 10 do decálogo).

E, de novo, quanto ao travessão: numa carta dirigida a sua irmã, de 20 de maio de 1885 (KSB 7.53), ele afirma que para ele não há nada que comece até depois do travessão, o que revela a preferência do autor por refletir sobre seu próprio processo reflexivo, mais do que sobre a realidade em si, como superação de si ou aquisição de consciência.

3. Em terceiro lugar, o tom. Nietzsche escreve cada frase como se se tratasse do que é mais radical e definitivo. $\mathrm{O}$ tom, conveniente à época, para ensaios, conferências e tratados, é predominado pela humildade, é amável e aceita as convenções; não obstante, Nietzsche gosta de brandir termos como "forças e energias selvagens" como mostras de sua própria genialidade, termos tão estimados por Nietzsche como pelo vitalismo tão em voga na época, e que persistia no individual (no eu e na ausência de modéstia), num tom singular, radical, indiferente, inclusive despótico, frequente e proveitoso na linguagem das revoluções e das guerras, de emancipações e fatos violentos (ponto 10 do decálogo; surpreende a radicalidade das formas diante da liberdade de conteúdos, causa de uma interpretação, no extremo, rica e difusa).

$$
* \quad * \quad *
$$

Até aqui tratamos da corporeidade. Vamos a outro aspecto já aludido, sobre o qual se singulariza o estilo de Nietzsche: a inserção de elementos poéticos na prosa (pontos 8 e 9), com que retomamos 
às interrogações ainda em aberto: como escrever? Como transmitir o pensamento?

A utilização da poesia, portanto, entendida como liberdade ou loucura consentida, consensual, permite falar daquilo que não existe numa língua apartada de prosaísmos rotineiros e bordões, se torna evidente em parágrafos como o seguinte:

- Um estranhamento profundo, uma frieza e uma sobriedade contra tudo que é contemporâneo, de acordo com a época: e, como desejo supremo, o olhar de Zaratustra, um olhar que vê, de uma distância descomunal, todo o fato homem, - vê abaixo de si... A uma tal meta - que sacrifício não lhe seria adequado? Que "superação de si”? Que "negação de si!" (FW/CW, Prefácio, KSA 6.12)

Como sabemos, o signo de identidade por antonomásia da poesia é a repetição: repetição de pé de verso, de estrofe, de estribilho, de rima, de assonâncias... repetição que contrasta com a caducidade e a transitoriedade, ao despertar a ilusão de que é possível deter o tempo físico e o espaço. Graças à repetição, rompe-se a direção do texto, do tempo, o som é antecipado. Em virtude da sonoridade, a poesia, a linguagem dos deuses, não precisa de nenhuma outra justificação. É livre e autotélica. Sua leitura rítmica libera o texto da "tirania" do mundo prosaico e o torna excepcional, motivo pelo qual o poeta se vincula com o marginal, excepcional, ritualístico, cultuado, festivo.

Assim, neste pequeno parágrafo se repetem tanto os artigos: "uma", "um", como o pronome interrogativo "que"; os substantivos, de forma total o parcial: "época"; "Vê, vê sob si"; "que superação de si”! Que negação de si!". Todas essas repetições produzem um som similar, próximo ao que a rima produz, e um movimento semelhante no ritmo. Nas três há consonantes próximas no principio no final, uma estrutura trocaica e datílica semelhante; finais como "estranho, frio, sóbrio", cujo sentido guarda um parentesco indubitável. O que se tem como prosa parece uma enumeração de elementos distintos, 
García, C. G.

se aproxima do sortilégio através da poesia, através do vínculo de termos unidos (normalmente três) a partir da sonoridade. ${ }^{6}$

Essa repetição, a variação frequente do semelhante, se alterna com o desigual (ponto 9). A assimetria prosaica rompe a simetria poética, cujo efeito transforma-se numa intensificação do expressado. Aquilo que é o mesmo, o que se insinua com meios poéticos se expressa programaticamente com ajuda da ruptura que a prosa implica, pois Nietzsche interrompe a expectativa de repetição do leitor e, com isso, todo tipo pressuposição, com que retoma o domínio do texto.

Enfim, a lírica, tendo superado seu receio inicial, pois a acusava do surgimento de um "proveito supersticioso", lhe serviu para dotar seu Zaratustra de uma espécie de prosa poética. Assim, personagens que transcendem a palavra, como Zaratustra, falam em versos ou numa prosa rítmica, criando uma música compreensível a todo ouvido, não, em último caso, por sua característica de vincular fenômenos acústicos e movimentos rítmicos que, armazenados no inconsciente, precedem a compreensão racional. Dito de outro modo: o efeito sensível, emocional, uma magia que antecede a compreensão do proferido (ponto 8). Os versos e sua estrutura envolvente, cerrada, obrigam o leitor, o ouvinte, a adotar as orações como verdades irrefutáveis sacralizadas pela música, a qual, de uma forma puramente emocional, instintiva, seduz o leitor.

Nietzsche envolve suas sentenças de versos e rupturas morais cuja argumentação se baseia numa intensificação emocional manifesta em sinais acústicos, corporais. $\mathrm{O}$ ritmo, mais antigo que as palavras e, não obstante, conatural a elas, conduz a um território que se encontra para além do bem e do mal: "Com sons é possível seduzir os homens em direção a todo erro e a toda verdade: quem poderia refutar um som?" (FW/GC 106, KSA 3.463). Poder-se-ia, inclusive, afirmar, de acordo com o que foi expresso no aforismo 80 de $A$ gaia ciência, que o que Nietzsche que almejava através do estilo de seus escritos era

6 Cf. Schlaffer, 2007, p. 34.

186 | Cad. Nietzsche, Guarulhos/Porto Seguro, v.41, n.1, p. 171-191, janeiro/abril, 2020. 
recuperar o que a tragédia grega havia perdido na historia de sua transmissão: voz, mímica, ritmo, movimento corporal. Poder-se-ia supor que Nietzsche pretende criar a obra de arte total retomando elementos da ópera: "Deve-se acreditar nas personagens da ópera não ‘pelas palavras', mas pelo som! Essa é a diferença, essa é a bela artificialidade, por causa da qual se vai para a ópera" (FW/GC 80, KSA 3.437). Trata-se de contradizer a natureza em nome de algo maior, de o corpo escrever e ser dotado de voz.

$\mathrm{E}$, a partir do corpo, retornamos à dança, que não é, sem a música e a poesia, expressão da embriaguez dionisíaca, do estado necessário para a criação artística. A dança, linguagem poética do corpo, o eleva, de sorte que o ser humano se transcende a si mesmo: de artista se torna obra de arte; e mais, a dança implica tornar-se movimento e, com ele, participar do movimento universal (pensese no aspecto ritual da dança, reservada para celebrar grandes acontecimentos). A afirmação dos instintos, do corpo, da vida, é inerente à dança; abarca a mediação de duas esferas contrapostas: produz um equilíbrio entre céu e chão, medeia o visível e o invisível, reconcilia o espiritual e o corporal. Ensina os seres humanos a transcender, a voar, a ligeireza que a filosofia deve aprender, tal como se afirma em Assim falava Zaratustra: "E quando isso for meu alfa e meu ômega, que torna leve todo peso, todo corpo se torna dançarino, todo espírito, pássaro". Dito de outra forma: a sabedoria do bailarino é graciosa, donaire que burla a sisudez. Mais adiante, ele afirma que a sabedoria do dançarino é a sabedoria do pássaro: "Vê! Não há acima e abaixo algum. Lança-te em volta, para cima, de volta, tu, o leve! Canta! Não fales mais!"' (Za/ZA, Os sete selos 7, KSA 4.291).

Então o bailar, a estabilidade na instabilidade, como uma corda frouxa, se converte numa forma de determinar esteticamente; daí que Nietzsche, como bem afirma Luis Enrique de Santiago de Guervós, teria querido que suas palavras, que suas frases, "cantassem como se fossem música e que suas palavras se movessem como numa dança" Guervós (2004, p. 458). Por isso, ele diz em Crepúsculo dos ídolos: 
García, C. G.

Aprender a pensar (...) - que o pensamento deve ser aprendido, como a dança deve se aprendida, como uma espécie da dança. (...) Ou seja, não se deve subtrair toda forma de dança do ensino preparatório. Pode-se dançar com pés, com conceitos, com palavras; tenho ainda de dizer que se deve fazer isso também com a pena - que se deve aprender a escrever? (GD/ CI, O que falta aos alemães 7, KSA 6.109-110)

Isto é: a palavra, antes entendida como forma de imobilizar, de simplificar e inclusive de mentir, se libera dos grilhões da linguagem graças à música, ao poema. A lírica fornece ritmo às palavras e, com isso, ligeireza, uma perspectiva a partir do "ver com profundidade". Nietzsche elevou sua prosa com ajuda de elementos próprios da "língua dos deuses", a saber, as orações em prosa permitem, ou pelo menos a paráfrase, um reordenamento sintático, operação que a poesia não aceita, que obriga o leitor a assumir as orações como certezas absolutas não sujeitas a nenhuma modificação, menos ainda por estar submetidas ao efeito poético da beleza que a musicalidade emana. Como o próprio filósofo sublinhava em $O$ nascimento da tragédia, na cultura grega, o poeta e o músico são idênticos. Trata-se, portanto, através da utilização de tons líricos, de um retorno da prosa filosófica à origem, à música. Serve como exemplo o fato de que cada parte do Zaratustra termine como uma canção, ou bem que, em A gaia ciência, o autor se transforme em cantor. É precisamente o jogo alternado entre a euforia poética, isto é, o jogo entre a apreensão de uma verdade superior inquestionável e a sobriedade da razão, expressa através do comedimento da prosa, o que conquista a cumplicidade de leitor de Nietzsche, ainda antes de que este tenha entendido a totalidade do escrito.

Cito, como recapitulação, o fragmento póstumo:

O compreensível na linguagem não é a própria palavra, mas o som, a intensidade, a modulação, o tempo com que uma sequência de palavras são faladas - em resumo, a música atrás das palavras, a paixão atrás dessa música, a pessoa atrás dessa paixão: portanto, tudo aquilo que não pode ser escrito (NF/FP do verão-outono de 1882, 3[1], KSA 10.89). 
Isso nos leva a responder à questão aberta com a sentença que fala ou canta Zaratustra: "Apenas na dança sei falar, por símiles, das coisas superiores" (Za/ZA, A canção fúnebre, KSA 4.144), quer dizer, atrás do escrito está o proferido; atrás da palavra recitada está o canto; atrás do canto, a dança, e, com isso, a vida. $O$ estilo, e com isto remetemos à fórmula inicial, já citada, é um bailar, dança, é o desejo de transcender a palavra com os meios da escrita.

$$
* * *
$$

Em Nietzsche, o "grande estilo" significa, portanto, desejo de intervir na vida, ou, como diz Guervós, o grande estilo é a expressão da vontade de potência (Guervós, 2004, p. 258). Além disso, Nehamas afirma que Nietzsche emprega "gêneros e estilos variados para que sua presença como autor se torne, literalmente, inolvidável" (Nehamas, 1985, p. 57). Os múltiplos estilos de Nietzsche se explicam, diz Nehamas, a partir de sua intenção de infiltrar-se no mundo dos leitores através de sua própria escrita, que, por sua vez, não é senão o produto de sua própria presença como autor, de sua vida.

$\mathrm{O}$ estilo, enfim, entendido como una ferramenta de conhecimento, e mais ainda, de transcendência dos limites da escrita e de transformação do leitor e de seu entorno:

Aqui está um leitor; ele não percebe que eu o observo. Eu o conheço faz tempo. - Uma cabeça medrosa: não há prejuízo em ser lido por ele. - Mas ele se transformou inteiramente: fui eu quem o transformou?

Vírgulas, pontos de interrogação e vocativos, e o leitor devia dar seu corpo e mostrar que o que se movimenta também move.

Lá está ele. Ele está inteiramente transformado.

Moral: deve-se aprender a ler bem; deve-se ensinar a ler bem.

(NF/FP de setembro-novembro de 1879, 47 [7], KSA 8.618-9). 
García, C. G.

\section{Nietzsche: Stylistics About a New Language of Thought}

Abstract: The article intends to analyze Nietzsche's style. Nietzsche uses language in order to ground and criticize established knowledge. Thus, he leads the raw-material of the artist, the language, to a crisis. He tries, by means of a renewed way of writing, to promote the creation of a more artistic world. Tracing a relationship between style and life, Nietzsche makes corporeality play a key role in his writings.

Keywords: style, language, body, life.

\section{Referência}

BENN, Gotffried. Lyrik des expressionistischen Jahrzehnts. München: dtv, 1962. . Ausgewählte Briefe. Wiesbaden: Limes, 1957.

BLECKWENN, Helga: “Der Stil soll leben'. Nietzsches Lehre vom Stil - aus didaktischer Sicht interpretiert“. In: ERZGRÄBER, Willi \& GAUGER, HansMartin (eds.): Stilfragen. Tübingen: Gunter Narr Verlag, 1992.

GAUGER, Hans-Martin: "El culto a Nietzsche en Alemania". In: Estudios Nietzsche 7, 2007, pp. 123-139.

GONZÁLEZ, Barberán: La recepción de Nietzsche en la literatura alemana. Albacete: Ediciones de la Diputación de Albacete, 2000.

GUERVÓS, Luis Enrique de Santiago: Arte y poder. Aproximación a la estética de Nietzsche. Madrid: Trotta, 2004.

KOOPMANN, Helmut: Deutsche Literaturtheorien zwischen 1880 und 1920. Eine Einfiihrung. Darmstadt: Wissenschaftliche Buchgesellschaft, 1997.

MANN, Thomas: Betrachtungen eines Unpolitischen. Frankfurt am Main: Fischer, 1983.

NEHAMAS, Alexander: Nietzsche. La vida como literatura. Trad. Ramón J. García. Madrid: Turner, 1985.

190 | Cad. Nietzsche, Guarulhos/Porto Seguro, v.41, n.1, p. 171-191, janeiro/abril, 2020. 
Nietzsche: Estilística para uma nova linguagem do pensamento

NIETZSCHE, Friedrich. Sämtliche Werke. Kritische Studienausgabe in 15 Bänden. München: dtv, 1999.

. Sämtliche Briefe. Kritische Studienausgabe. München: dtv, 2003.

RILKE, Rainer Maria: Malte Laurids Brigge. Leipzig: 1910.

SAFRANSKI, Rüdiger: Nietzsche. Biographie seines Denkens. Munique: Hanser, 2000.

SCHLAFFER, Heinz: Das entfesselte Wort: Nietzsches Stil und seine Folgen. Múnich: Hanser, 2007.

Enviado: 11/09/2019

Aceito: $21 / 11 / 2019$ 